\title{
MENOPAUSE AND THE MENSTRUAL EQUITY AGENDA
}

\section{JENNIFER WEISS-WOLF*}

I was in fifth grade, the year 1978, and the weathered purple- and orange-covered paperback copy of Are You There God? It's Me, Margaret. was finally mine to check out of the school library for an entire week. I read it cover to cover that first night, and surely a dozen times over in the years that followed. I have since reflected upon the extraordinary gifts Judy Blume bestowed in Margaret: enabling children to be seen, respected, and met right when and where it mattered. She validated the most mundane, yet oddly prolific, questions about periods that were clearly on the minds of many.

Four decades later, it is fair to say that the most meaningful moments of my legal career have been spent considering the very same topic - menstruation — in a quest to ensure its political centrality to issues of social justice, democratic participation, and gender equality. For my own part, commitment to menstrual equity has entailed examining our current laws and systems to see where discrimination and bias exist and persist - from public benefits to tax codes to education - and then forging the arguments to reverse that. And then, importantly, reimagining, crafting, and advancing new and more equitable policies in their place.

The Trump era was something of a fulcrum for this advocacy, despite its inauspicious start. Recall the first debate of Republican presidential candidates in August 2015 when Trump railed at Megyn Kelly for having "blood coming out of her wherever." Even in a highly charged partisan environment, our movement racked up a multitude of legislative wins in Congress, in the states, and around the world - new laws that made menstrual products tax-free, more affordable and accessible, and freely provided in schools, shelters, jails, and prisons.

\footnotetext{
${ }^{*}$ Vice president and the inaugural women and democracy fellow of the Brennan Center for Justice at NYU Law. An attorney, author, and passionate advocate for issues of gender, politics, and menstruation, she was dubbed the "architect of the U.S. campaign to squash the tampon tax" by Newsweek. Her 2017 book Periods Gone Public: Taking a Stand for Menstrual Equity was lauded by Gloria Steinem as "the beginning of liberation for us all.” A regular contributor to Newsweek and Ms. Magazine, Weiss-Wolf's writing and work have been featured by The New York Times, Washington Post, Los Angeles Times, TIME, The Economist, Cosmopolitan, Harper's Bazaar, Teen Vogue, Marie Claire, Good Morning America, NPR, PBS, NBC, and $C B S$, among others. She is also a contributor to the 2018 young adult anthology, Period.: Twelve Voices Tell the Bloody Truth.
} 
Still, I would not quite have predicted that all I'd gleaned about the politics of periods would have led me to this particular essay: a calling to go public with menopause.

And yet, it is also the inevitable sequel to my story. To all our stories.

Flashback to January 2020. Things were looking ... promising? (Yes, I had no idea.) I was headed to southern California to attend the premiere of Pandora's Box: Lifting the Lid on Menstruation, the first feature-length documentary film about global menstrual activism. ${ }^{1}$ Bookending that trip was stops in Michigan ${ }^{2}$ and Washington ${ }^{3}$ to lobby local leaders in support of campaigns to eliminate the "tampon tax" in each of those states. While staying overnight in Seattle between meetings, I splurged for the hotel spa package - a detail I remember all too vividly, only because as soon as I approached the pristine treatment table, my period arrived like a grisly crime scene. At fifty-two years old, I could debate menstrual policy like a pro in legislative chambers and before editorial boards, but behind the scenes I still wasn't spared such messy moments.

By the time I returned from the trip, memory of the macabre massage quickly receded as news of the pandemic took over. As of early February, Seattle was the United States epicenter of the COVID-19 crisis. That red-eye home was the last flight I would take in 2020. Within weeks, I experienced a slew of "lasts" that I can still barely wrap my brain around - my last time in the audience of a Broadway show, my last round of drinks inside a local brew pub with friends, my last visit to my daughter's college dorm.

There was another "last" for me that coincided with the pandemic. My last period. When it didn't come in March or April or May, I figured my body might just be responding to the stress of sheltering in place and the trauma unfolding around us. I assumed the same about the sudden onset of exceptionally dry, brittle hair. How to explain my rapidly expanding middle? Surely the "Quarantine-15" and all the comfort food I was consuming. Diminishing libido? An empty nest full of college birds flown

\footnotetext{
${ }^{1}$ Carmen Rios, The Ms. Q\&A: The Women Behind 'Pandora's Box' Want You to Talk About Menstruation, Ms. MAGAZINE (Feb. 10, 2020), https://msmagazine.com/2020/02/10/the-ms-qa-the-women-behindpandoras-box-want-you-to-talk-about-menstruation/ [https://perma.cc/P5WZ-52RM].

${ }^{2}$ Jennifer Weiss-Wolf, See You in Court, Michigan. The Tampon Tax Is Sex Discrimination, Newsweek (Aug. 14, 2020), https://www.newsweek.com/see-you-court-michigan-tampon-tax-discrimination-opinion1525230 [https://perma.cc/D4HH-B8LR].

${ }^{3}$ Jennifer Weiss-Wolf, End the Discriminatory Tampon Tax in Washington State, SEATtLe Times (Feb. 13, 2020), https://www.seattletimes.com/opinion/end-the-discriminatory-tampon-tax-in-washington-state/ [https://perma.cc/H3UC-6MGB].
} 
home was not exactly conducive to romance. Insomnia, brain fog, fatigue . . yes, yes, and yes. Weren't we all experiencing that?

It was September when I finally, fully deduced what was going on. I was more than a little relieved to embrace the reality. This was menopause.

Despite what I thought I knew to be true about menopause, the transition for me was not one marked by shock and sadness or denial and depression. In fact, quite the opposite, I found it rather intriguing, freeing, even a little exhilarating. Sort of like how I first considered periods back in the 1970s through the eyes of Judy Blume's pre-teen protagonist. As much as I have relished being dubbed a "tampon crusader" for my menstrual policy work, how could I not also revel in the chance to experience something totally new within my own body and being - something that happens to half the population and places me in the company of many millions who came before?

Here is the part where you might expect me to decry the lack of readily available information and candid talk. How my futile search for a Margaret-style bible of menopause blindsided me, steered me all wrong. I was bracing for that myself! Among the very first articles I read when I began digging in was a 2019 New Yorker essay lamenting "Where Are All the Books About Menopause?"4

Except that's not entirely how I experienced it. As I gathered up materials to educate myself, I was struck that there appeared to be a wide array from which to choose. Gail Sheehy's best-selling classic The Silent Passage seemed like a reasonable start. The singular, lush green leaf that donned the cover looked, well, ubiquitous; the overarching tone a smidge dated. Even the most current edition echoes with lingo from its original 1990 release. Still, Sheehy's embrace of empowerment and energy was reassuring.

There are a small handful of other genres that readily center menopause, too-many entries in the personal health and wellness category, as well as raucous memoirs like The Madwoman in the Volvo, ${ }^{5}$ and a recently published, beautifully rich historical volume, The Slow Moon Climbs. ${ }^{6}$

\footnotetext{
${ }^{4}$ Sarah Manguso, Where Are All the Books About Menopause?. THe New Yorker (June 17, 2019), https://www.newyorker.com/magazine/2019/06/24/where-are-all-the-books-about-menopause [https://perma.cc/NV2M-TAAM].

${ }^{5}$ Sandra Tsing Loh, The Madwoman in the Volvo: My Year of Raging Hormones (2015).

${ }^{6}$ Susan Mattern, The Slow Moon Climbs: The Science, History, and Meaning of Menopause (2019).
} 
There's no shortage of articles to consume, either, from fashion magazines and feminist blogs to health and business journals. A lengthy piece in Oprah Magazine was remarkably thorough. ${ }^{7}$ In a celebrity tell-all, Glamour featured wisdom from the likes of Oprah Winfrey herself, along with luminaries like Michelle Obama and Emma Thompson. ${ }^{8}$ I especially loved InStyle's "Of Course Gen X Is Doing Menopause Differently." (I'm in good company if my teenage idols from The Breakfast Club are menopausal too, right?!) And a heady series in Harvard Business Review led with segments like "Is Menopause a Taboo in Your Organization?"10 and "It's Time to Start Talking About Menopause at Work." 11

Despite all the cheerleading, though, there was this odd chasm, a subtle disconnect in all I was reading. Embedded in nearly every bit of commentary was a presumptive sexist, ageist trope - jokes about our overheated brains and bodies, the expectation of our diminishing utility and presence.

Menopause is neither a punchline nor permanent purgatory. It is fascinating and telling, in fact, how many people report feeling far better about life on the other side of peak fertility years. As one researcher described the eventual transition: "[Women] have more hope, more happiness with their bodies, more optimism around their career, more excitement about their family. As we move into menopause, it's that notion of being more independent and more competent - and that's often a totally positive thing." ${ }^{12}$ And from that Oprah Magazine article: "You might even call it the discovery of a lifetime:

\footnotetext{
${ }^{7}$ Robin Marantz Henig, The Ultimate Guide to Dealing with Menopause, OpRAH MAG. (Oct. 6, 2020), https://www.oprahmag.com/life/health/a28928539/menopause-symptoms/ [https://perma.cc/DZS3-TAAG].

${ }^{8}$ Ten Celebrities Who Have Spoken Out About Menopause, Glamour (Oct. 6, 2020), https://www.glamour.com/gallery/celebrities-who-have-spoken-out-about-menopause [https://perma.cc/47KQ-JTNK].

${ }^{9}$ Amber Sparks, Of Course Gen X Is Doing Menopause Differently, InStyle (Apr. 9, 2020), https://www.instyle.com/beauty/health-fitness/gen-X-menopause [https://perma.cc/3UBM-R2G6].

${ }^{10}$ Megan Reitz, Marina Bolton \& Kira Emslie, Is Menopause a Taboo in Your Organization?, HaRv. Bus. REV. (Feb. 4, 2020), https://hbr.org/2020/02/is-menopause-a-taboo-in-your-organization [https://perma.cc/YUL4-KFG9].

${ }^{11}$ Jeneva Patterson, It's Time to Start Talking About Menopause at Work, HARV. Bus. Rev. (Feb. 24, 2020), https://hbr.org/2020/02/its-time-to-start-talking-about-menopause-at-work [https://perma.cc/BZE9-QNQM].

${ }^{12}$ Macaela MacKenzie, 1.3 Million Women Enter Menopause Each Year. We Have to Stop Ignoring Them, GlAMOUR (Oct. 7, 2020), https://www.glamour.com/story/its-time-to-stop-ignoring-menopausal-women [https://perma.cc/V2VD-ADBA].
} 
that menopause, far from being the tragic end of the best part of [your] existence, can actually be a threshold, a gateway, the passage to the you you've been waiting your whole life to become."13

And therein lies my revelation. It is due time for our full-throated rebuke of the societal forces that have thus far managed to minimize or marginalize menopause. It should instead be central to the public discourse, a driver for policy and innovation, and at the heart of today's social and political mobilizations to ensure gender equity and equality-including within the menstrual equity movement.

This can be a multi-generational charge, starting with my own Gen X cohort. With 65 million born after 1965, an estimated 6,000 of us now enter menopause each day-and are perhaps better equipped than any to experience it with the kind of cool, pragmatic acceptance we are known for. We are joined by our post-menopausal moms and mentors-legions of powerhouse Boomers who are fueling inspiration everywhere, including as the first woman (and Black and South Asian) Vice President of the United States, as Speaker of the House and across Capitol Hill, in C-suites and board rooms, on Hollywood screens and Broadway stages, and throughout all industries and communities. Together, our generations' accumulated wisdom and experience continue to contribute profoundly to the economy, to culture, and to public life.

There is also a ripe opportunity to tap the next two generations. Millennials, now the largest generation in the U.S. workforce, are or will soon be in the throes of perimenopause (the period that precedes menopause and lasts for as long as a decade). Gen $\mathrm{Z}$ teens and twenty-somethings already have a healthy appetite for, and extraordinary sophistication about, inclusive gender and generational politics. All this combined idealism, creativity, and savvy makes for a mighty organizing footprint.

What is it we can accomplish together? Beyond fuller bodily fluency, we can make menopause the catalyst for better, more representative policy with regard to health, the economy, and education; the fuel for new research and product development; and the source for more rich and dynamic public storytelling.

Here are some areas ripe for further exploration and advocacy:

- According to researchers at Johns Hopkins University, only twenty percent of medical school residency programs in the United States have a formal menopause

\footnotetext{
${ }^{13}$ Henig, supra note 7.
} 
curriculum, even though it encompasses myriad specialties, from gynecology to internal medicine to psychiatry. ${ }^{14}$ Doctors' inadequate understanding of women's experiences is well-documented and too common, overall; this is too often the case for those who are transgender, intersex, nonbinary, or gender diverse, as well. For every one of us who experiences menopause, its sweeping exclusion is an outright breach. Modern medical education must be fully reimagined to include its study and consideration.

- Another stunning twenty percent statistic: one in five people in the United States workforce are now in menopause. ${ }^{15}$ For those who are afflicted by the most debilitating effects, there can be potential impacts on productivity. Employers must balance multiple interests - tapping top performance, equitably utilizing employee benefits (like paid sick time), avoiding discriminatory action - while minding bottom lines. A best-practice menopause policy agenda for workplaces is sorely needed.

- Recent data shows that a full third of those who experience extreme pain or discomfort on account of menopause report using cannabis to ameliorate its impact. ${ }^{16}$ As public support continues to grow for legalization of marijuana, there are key drug policy considerations to weigh so that we do not inadvertently create disparate outcomes, along with scientific support to show the potential health risks and benefits.

- A possible link between menopause and COVID-19? Researchers are now suggesting that waning estrogen levels could equate to longer-lasting impact from the virus among those who have gone through menopause. ${ }^{17}$ This must be immediately understood and addressed.

\footnotetext{
${ }^{14}$ Mindy S. Christianson et al., Menopause Education: Needs Assessment of American Obstetrics and Gynecology Residents, 20 MenOPaUSE 1120, 1120-25 (2013).

${ }^{15}$ Aisha Hassan, Menopausal Women Aren't Being Supported at Work—and It's Affecting Companies' Bottom Line, QUARTZ (Mar. 20, 2019), https://qz.com/1576313/menopausal-women-arent-being-supportedat-work/ [https://perma.cc/5E85-P7US].

${ }^{16}$ N. Am. Menopause Soc'y, Cannabis Use for Menopause Symptom Management, MediCALXPREss (Sept. 28, 2020), https://medicalxpress.com/news/2020-09-cannabis-menopause-symptom.html [https://perma.cc/53VB-6NN2].

${ }^{17}$ Nicola Davis, Calls to Investigate Possible Link Between Menopause and Covid Risk, GuARDIAN (Dec. 4, 2020), https://www.theguardian.com/world/2020/dec/04/calls-investigate-possible-link-menopause-covidrisk [https://perma.cc/7VER-625E].
} 
- After a century of limited advances in menstrual product innovation, there is now a thriving alternative commercial industry, largely focused on youth audiences and green alternatives, promoting everything from period underwear to reusable or compostable pads, tampons, and applicators. A comparable menopause market has extraordinary potential - everything from tech and telemedicine, to sweat-wicking fashion and healthy lubricants - not only for consumers but for burgeoning secondcareer female entrepreneurs, as well. ${ }^{18}$ These advances also raise potential legal issues around consumer protection and privacy.

- How menopause is talked about and covered by the media matters enormously, too. Fun fact: It made its prime-time debut in 1972 on All in the Family when Edith Bunker gave Archie an extra dose of agita about hot flashes; the episode broke barriers and won awards. Last year, Kristin Scott Thomas made a cameo on Fleabag to drop some powerful F-bomb-laden truth — calling menopause the thing that makes us "free, no longer a slave, no longer a machine with parts. You're just a person." It is time to be this deliberate and bold in how we reflect menopause in every aspect of public life - on screen, stage, in literature, and in the real-time news - because it will not only educate the masses but drive better societal outcomes.

Back in 1978, the same year I was introduced to Margaret, Gloria Steinem published a provocative satire about the reverse weaponization of periods on patriarchy and oppression. ${ }^{19}$

Now, its next chapter is upon us: menopause as the gateway to a new, vital law and policy agenda that is committed to acknowledging, accepting, and even elevating the value of our no-longer bleeding bodies and our lives at all stages. Period. Full stop.

\footnotetext{
${ }^{18}$ Mariel Padilla, 'It's Never Too Late': The Entrepreneurial Spirit of Older Women, THE $19^{\mathrm{TH}}$ (Jan. 1, 2021), https://19thnews.org/2021/01/entrepreneurial-older-women/ [https://perma.cc/9V5F-UL5M].

${ }^{19}$ Gloria Steinem, If Men Could Menstruate, 6 Women’s Reprod. Health 151, 151-52 (2019).
} 